\title{
Mathematical Modeling of a developed Central Receiver Based on Evacuated Solar Tubes
}

\author{
Basil. H. Ali ${ }^{1, a}{ }^{*}$, S. I. Gilani ${ }^{1}$, and Hussain H. Al-Kayiem ${ }^{1}$ \\ ${ }^{1}$ Mechanical Engineering Department, Universiti Teknologi PETRONAS, 32610 Bandar Seri Iskandar, Perak Darul Ridzuan, Malaysia
}

\begin{abstract}
Solar central receiver plays a considerable role in the plant output power; it is one of the most important synthesis in the solar power tower plants. Its performance directly affects the efficiency of the entire solar power generation system. In this study, a new designed receiver model based on evacuated solar tube was proposed, and the dynamic characteristics of the developed receiver were investigated. In order to optimise and evaluate the dynamic characteristics of solar power plant components, the model investigates the solar radiation heat conversion process through the developed receiver, where the energy and mass conservation equations are used to determine the working fluid temperature and state through the receiver parts, beside the calculation and analysis of the thermal losses.
\end{abstract}

\section{Introduction}

With the growing energy consumption and the potential for oil depletion associated to the problems of global warming, central receiver system (CRS) power plants represent the most viable choice to replace fossil fuel power plant electricity generation. The solar power tower plant main systems consist of the collector system, which is composed of a heliostat and a tower, thermal storage system, power and auxiliary system. Solar power tower plants operate by increasing the solar concentration ratio and the amount of direct solar radiation, where the energy efficiency of the receiver can be increased.

External solar receiver and solar cavity receiver are the main existing types of solar power tower receivers, when the first experience a problem of huge amount of heat losses, the second deals only with a certain layout of the solar field, and both are designed to a certain level of power. The need for a new design with less heat loss value is essential, and when the evacuated tube collector had a good achieve to reduce the heat losses, then the objectives of this research is oriented to complete this work.

A review of studies on the central receiver solar thermal power plants is presented by Omar Behar et.al[1] in which he took an overall review of the solar power tower major components, including the heliostat field, the solar receiver and the power conversion system. Another review of Concentrated solar power plants design methodology is performed by H.L. Zhang[2]. When the current status of the world solar central receiver systems projects, and technologies is presented by Manuel Romero et.al [3]. Javier Munoz et.al [4] proposed a conceptual design of a solar boiler, and how their ideas come from the design of the conventional steam boiler, except that the heat comes from the heliostat field which concentrate the solar radiation on the walls of the solar collectors, instead of coming from hot gas. Z.D. Cheng et.al [5]develop a general-purpose numerical method for improving design and simulation tools for the concentrating solar collectors (CSCs) of concentrated solar power (CSP) systems. A numerical code for the calculation of the solar power collected in a central receiver system is done by Erminia Leonardi et.al[6]they used a new Fortran computer program for their code. And when the design of solar receiver systems requires an accurate measurement for the amount of solar radiation and its behavior, an alternative method for calculation of semi-gray radiation heat transfer in solar central cavity receivers was suggested by Sonke.H et al [7]. For different working fluid type such as air, molten salt, many studies are executed. A modular ceramic cavity receiver for high temperature, high Concentration Solar Applications is proposed by I. Hischier et al [8]. Another study is presented by A. Kribus et al [9] who present a guide for multistage solar receiver design for high temperature. Recently a pioneer solar power tower plant constructed in china opening the way for many researchers to apply their ideas of solar power tower component designing and studies. Chao $\mathrm{Xu}$ et al [10] provides an energy and exergy analysis of this mentioned solar power tower plant. Modeling and dynamic simulation of the collector and receiver system of $1 \mathrm{MWe}$ DAHAN solar thermal power tower plant is performed by Qiang $\mathrm{Yu}$ et al[11]. Another research in modeling and simulation of $1 \mathrm{MW}$ DAHAN solar thermal power tower plant is done for the thermal plant integrated system by Ershu Xu et al [12]. And Zhihao Yao et al [13]

\footnotetext{
${ }^{a}$ Corresponding author: basil4eng@yahoo.com
} 
present a modeling and simulation of the plant central receiver system. The heliostat field layout design HFLD software is used to calculate the performance of the plant, and TRNSYS plant model is developed for the plant simulation

\section{Developed receiver features and parameters}

The developed receiver is planned to operate at Malaysians weather, under project supported by UNEVERSITI TEKNOLOGY PETRONAS for solar research purposes, conducted in the solar energy unit. The latitude Longitude of the suggested plant is $4^{\circ} \mathrm{N}, 101^{\circ} \mathrm{E}$ respectively. The field is planned to collect a maximum number of $20 \mathrm{Kw} / \mathrm{m}^{2}$ of solar radiation in the top of the tower, where the receiver will be located. The first phase of the receiver is planned to operate a $1.2 \mathrm{Kw}$ steam turbine. The main component and parameters of the receiver are the number of the used evacuated tube, which decide the interception area of the heat surfaces, the dimensions of the tubes and the arrangement of the tubes and steam separator, Figure (1) shows the developed receiver feature.

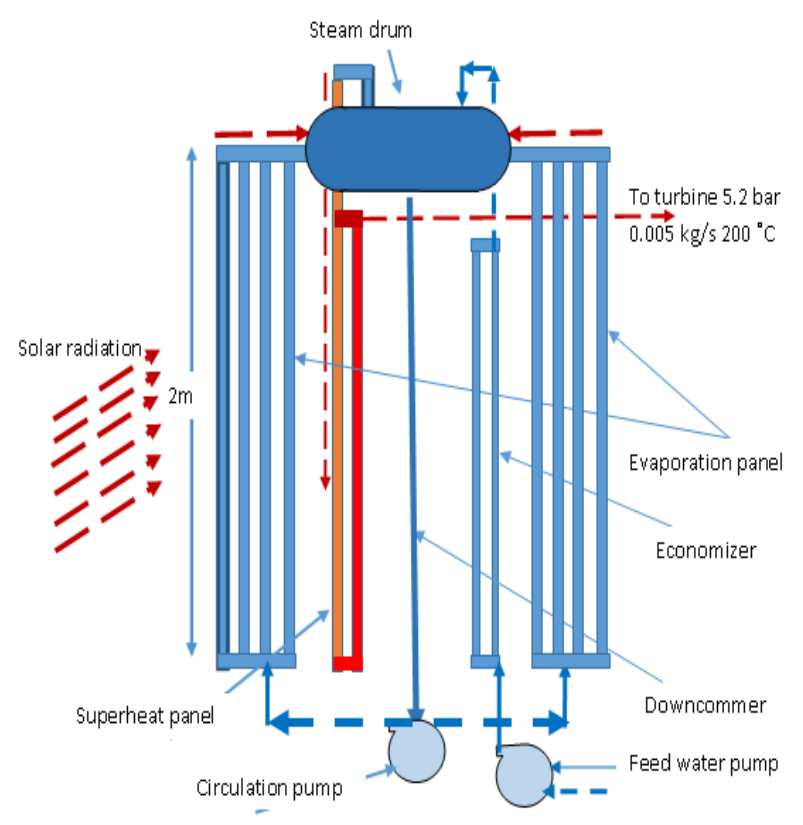

Figure 1. The developed receiver feature

\section{The receiver mathematical model}

For the suggested design of the receiver which composed of evaporator surface, steam separation drum and superheat surface, the mathematical model of this component is as follows

- The heat transfer model between the wall and heating surface,

- Heating surface model

- $\quad$ Steam separation drum model,
The heat transfer model is used to calculate the amount of heat transferred under various temperature differences. In the heating surface model the tube metal temperature and medium state parameter are calculated based on factors include the received solar energy, environmental heat loss, and heat transferred to the medium. Steam separation drum pressure and water level changes are also included in the model

\subsection{The Steam separation drum model.}

This model is divided into two regions,

- The vapor region

- The liquid region

Figure (2) describes the steam separation drum model configuration

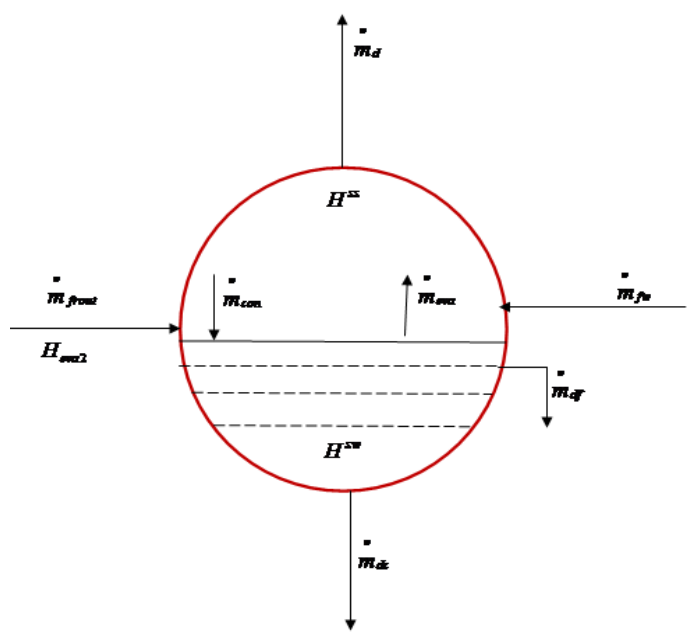

Figure 2. Steam separation drum model configuration

The mathematical model of the steam separation drum can be formulated as follows:

1. Mass conservation equation

$$
\frac{d}{d t}\left(\rho^{s w} V_{l-d r u m}+\rho^{s s} V_{g-d r u m}\right)=\dot{m}_{f w}+\dot{m}_{f r o u t}-\dot{m}_{d c}-\dot{m}_{d}-\dot{m}_{d f}
$$

2. Energy conservation equation

$$
\begin{aligned}
& \frac{d}{d t}\left(\rho^{s w} V_{l-d r u m} H^{s w}+\rho^{s s} V_{g-d r u m} H^{s s}\right)=\dot{m}_{f w} H_{f w}+\dot{m}_{\text {frout }} H^{s s} \\
& \quad \dot{m}_{\text {frout }}(1-x) H^{s w}-\dot{m}_{d c} H_{d o w n}-\dot{m}_{d} H^{s s}-\dot{m}_{d f} H^{s w}-Q_{m-d}
\end{aligned}
$$

3. Mass conservation equation for steam 


$$
\frac{d}{d t}\left(\rho^{s s} V_{g-d r u m}\right)=\stackrel{\bullet}{m_{\text {frout }} x-\dot{m}_{d}-\dot{m}_{\text {con }}+\dot{m}_{\text {eva }}}
$$

4. Energy conservation equation for steam

$$
\begin{aligned}
\frac{d}{d t}\left(\rho^{s s} V_{g-d r u m} H^{s s}\right) & =\dot{m}_{\text {frout }} x H^{s s}- \\
& \dot{m}_{d} H^{s s}-\dot{m}_{\text {con }} H^{s w}+\dot{m}_{\text {eva }} H^{s s}+Q_{g-m}
\end{aligned}
$$

$$
V_{g-\text { drum }}+V_{l-\text { drum }}=V_{\text {drum }}
$$

Condense steam flow

$$
\dot{m}_{c o n}=\frac{\dot{m}_{f w}\left(H^{s s}+H_{f w}\right)}{H^{s s}-H^{s w}}
$$

(6)

\subsection{Heat transfer model in the evaporation tubes}

Heat transfer model of the evaporation tube is classified into three types:

- $\quad$ Single-phase forced flow heat transfer

- Two-phase forced flow, nucleate heat transfer

- Two-phase forced flow heat transfer

Figure (3) describes the evaporation tube model configuration, the model assumptions are as follows:

$>$ Uniform fluid characteristics across the section of the tubes

$>$ Steady flow through the tubes

$>$ Ignore the axial heat conduction

$>$ The solar radiation flux is uniformly distributed along the tube length

$>$ The working fluid pressure in the tube is uniform

$>$ The drum pressure is used as characteristic parameter

1. Mass conservation equation:

$$
\frac{d}{d t}(\rho V)=\stackrel{\bullet}{m_{\text {frout }}-\dot{m}_{\text {frin }}}
$$

2. Energy conservation equation

$$
\begin{gathered}
\frac{d}{d t}\left(M_{j} T_{j}\right)=Q_{f}-Q_{a} \\
\frac{d}{d t}\left(M_{a} h\right)=\stackrel{m_{\text {frin }}}{ } H_{\text {eva } 1}-\stackrel{\bullet}{m_{\text {frout }}} H_{\text {eva } 2}+Q_{a} \\
Q_{a}=\alpha_{l} S\left(T_{j}-T_{a}\right)
\end{gathered}
$$

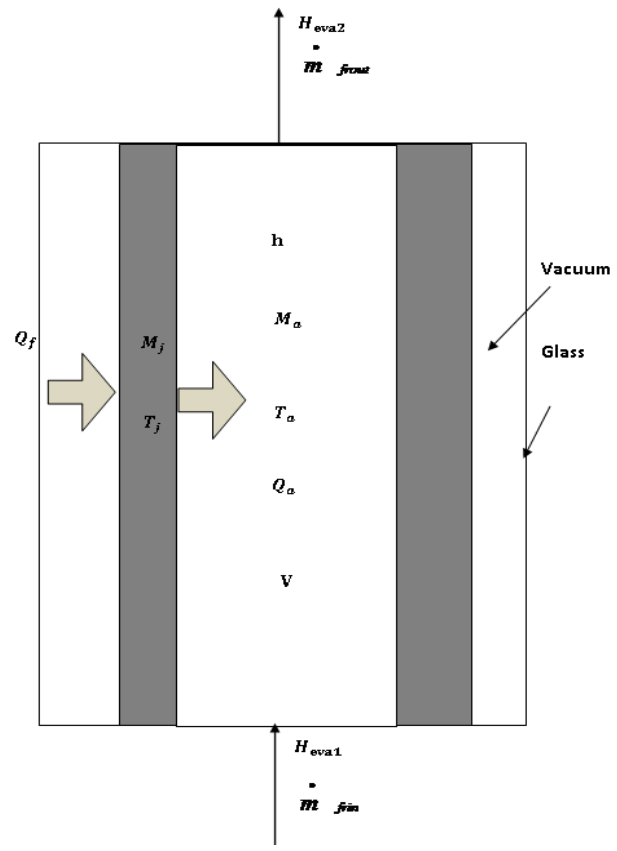

Figure 3. Evaporation tube model configuration

For heat transfer coefficient in single- phase fluid forced flow, using belt-Di tooth formula is

$$
\alpha_{c h t}=\frac{\lambda}{d} 0.023 \mathrm{Re}^{0.8} \mathrm{Pr}^{0.4}
$$

And for two phase heat transfer the value of $\alpha_{l}$ is found from

$$
\alpha_{l}=\alpha_{h f}+\alpha_{d l}
$$




$$
\begin{gathered}
\alpha_{h f}=0.00122\left[\frac{0.79 \lambda^{\prime} C_{p}^{\prime 0.45} \rho^{\prime 0.49}}{\sigma^{0.5} u^{\prime 0.29} \gamma^{0.24} \rho^{\prime 0.24}}\right] \times \\
\Delta t_{g r}^{0.24} \cdot \Delta p_{g r}^{0.75} \cdot S
\end{gathered}
$$

Where

$$
S=\left[1+2.53 \times 10^{-6}(\mathrm{Re})_{l x}^{1.17}\right]^{-1}
$$

And

$$
\begin{gathered}
(\mathrm{Re})_{l x}=\left[\frac{W_{2}(1-x) d}{u^{\prime}}\right] F^{1.25} \\
\text { If } \frac{1}{x_{t t}} \leq 0.1 \text { then } F=1.0
\end{gathered}
$$

$$
\text { And if } \frac{1}{x_{t t}}>0.1
$$$$
F=2.35\left(\frac{1}{x_{t t}}+0.213\right)^{0.736}
$$$$
x_{t t}=\left(\frac{1-x}{x}\right)^{0.9} \cdot\left(\frac{\rho^{\prime \prime}}{\rho^{\prime}}\right)^{0.05} \cdot\left(\frac{u^{\prime \prime}}{u^{\prime}}\right)^{0.1}
$$$$
\alpha_{d l}=0.023 \frac{\lambda^{\prime}}{d}\left[\frac{W_{2}(1-x) d}{u^{\prime}}\right]^{0.8}\left[\frac{u^{\prime} c p^{\prime}}{\lambda^{\prime}}\right]^{0.4} . F
$$

For heat transfer in two-phase fluid forced flow

$$
\begin{aligned}
& \text { When } \dot{m}_{\text {frout }}>800 \mathrm{~kg} / \mathrm{m}^{2} \mathrm{~s} \\
& y=1-0.1\left(\frac{\rho^{\prime}}{\rho^{\prime \prime}}-1\right)^{0.4} \times(1-x)^{0.4}
\end{aligned}
$$

$$
\begin{aligned}
N u=0.023 & \left(\frac{\rho^{\prime} W_{2} d}{\rho^{\prime \prime} v^{\prime \prime}}\right)^{0.8} \cdot\left(\operatorname{Pr}^{\prime \prime}\right)^{0.4} \\
& \times\left[x+\frac{\rho^{\prime \prime}}{\rho^{\prime}}(1-x)\right]^{0.8} \cdot y
\end{aligned}
$$

$$
\alpha_{l}=\lambda^{\prime \prime} / d \cdot N u
$$

$$
\text { When } \quad \dot{m}_{\text {frout }} \leq 800 \mathrm{~kg} / \mathrm{m}^{2} \mathrm{~s}
$$

Then,

$$
\begin{array}{r}
\alpha_{l}=1.16\left[\frac{12.5+0.025 W_{2}}{(x+0.001)-X_{e h}}\right. \\
\left.-\left(4650-8 \rho W_{2}\right)\left(x-X_{e h}\right)+1240\right]
\end{array}
$$

\subsection{Modeling of super heater}

1- Energy conservation equations

$$
\frac{d(M H)}{d t}=\dot{m}_{\text {supin }} H^{s s}-\dot{m}_{\text {supout }} H_{\text {supout }}+Q
$$

$\mathrm{M}$ is the mass of steam, which can be calculated by the following equation.

$$
M=\rho V
$$

2- The heat transfer between the working fluid and metal pipe is expressed as follows

$$
Q=K{\stackrel{\bullet}{m^{n}}}_{\text {supout }}\left(T_{m}-T_{2}\right)
$$

Where, $\mathrm{K}$ is the heat exchange coefficient between steam and metal pipe. The value of $\mathrm{K}$ is decided by the superheated design data, (n) as the index, $\mathrm{n}=0.8$.

The previous mentioned mathematical modeling, controlled the thermal performance of the developed solar central receiver. The primary phase receiver specifications are given in figure 1 that values are suitable to be a preliminary design, to analyze and check the result of its application for this feature, and will lead to optimize the size of the receiver component. 


\section{Conclusions}

\section{Results and discussions}

For the mentioned design parameters of turbine pressure, steam flow rate, and degree of superheat temperature. The values of enthalpy are picked from the steam table for the saturated water, and saturated steam as represented in table (1), Depending on the circulation pump pressure, the values of the enthalpy and the steam fraction $(x)$ in the drum inlet are determined. Where the drum inlet flow rate and circulation water flow rate are a control variables, there values are determined according to the rate of the collected solar radiation. The optimum surface area can be selected according to the image size and concentrated irradiance. For the selected tube dimension and assuming constant $0.4 \mathrm{~kW} / \mathrm{m}^{2}$ direct irradiance, table (2) represent the required amount of the input values of the system.

Table 1. Design Parameters value

\begin{tabular}{|l|l|}
\hline \multicolumn{1}{|c|}{ Parameter } & \multicolumn{1}{c|}{ Value } \\
\hline Turbine inlet Steam pressure & $5.2 \mathrm{bar}$ \\
\hline Saturated steam enthalpy $\boldsymbol{H}^{s s}$ & $2750 \mathrm{~kJ} / \mathrm{kg}$ \\
\hline Saturated water enthalpy $\boldsymbol{H}^{\text {sw }}$ & $640 \mathrm{~kJ} / \mathrm{kg}$ \\
\hline $\begin{array}{l}\text { Turbine superheat temperature at } \\
\boldsymbol{H}_{\text {supout }}\end{array}$ & $200{ }^{\circ} \mathrm{C}$ \\
\hline Steam flow rate $\boldsymbol{m}_{d}$ & $0.005 \mathrm{~kg} / \mathrm{s}$ \\
\hline
\end{tabular}

Table 2. Required amount of the developed receiver

\begin{tabular}{|c|c|c|c|}
\hline Parameter & Value & Parameters & Value \\
\hline $\begin{array}{l}\text { Inner Tube } \\
\text { diameter }\end{array}$ & $63 \mathrm{~mm}$ & SHP Q in & $0.4 \mathrm{~kW} / \mathrm{m}^{2}$ \\
\hline Tube length & $2000 \mathrm{~mm}$ & $\begin{array}{l}\text { FW pump } \\
\text { power }\end{array}$ & $0.15 \mathrm{~kW}$ \\
\hline $\begin{array}{l}\text { Number of } \\
\text { CW tubes }\end{array}$ & 8 & $\begin{array}{l}\text { CW pump } \\
\text { power }\end{array}$ & $0.05 \mathrm{~kW}$ \\
\hline $\begin{array}{l}\text { Number of } \\
\text { FW tubes }\end{array}$ & 2 & Separator V & 15 litters \\
\hline $\begin{array}{l}\text { Number of } \\
\text { SHP tubes }\end{array}$ & 2 & $\begin{array}{c}\mathrm{V} \text { of saturated } \\
\text { gas }\end{array}$ & $\begin{array}{l}0.358 \\
\mathrm{~m}^{3} / \mathrm{kg}\end{array}$ \\
\hline $\mathrm{CW} \mathrm{Q}$ in & $1.4 \mathrm{~kW} / \mathrm{m}^{2}$ & $\begin{array}{c}\mathrm{V} \text { of } \\
\text { saturated liq }\end{array}$ & $\begin{array}{c}0.0010904 \\
\mathrm{~m}^{3} / \mathrm{kg}\end{array}$ \\
\hline FW Q in & $3.2 \mathrm{kw} / \mathrm{m}^{2}$ & Required heat & $5 \mathrm{~kW} / \mathrm{m}^{2}$ \\
\hline $\mathrm{CW}$ bar & 6 bar & abarture area & $2 \mathrm{~m}^{2}$ \\
\hline
\end{tabular}

When the number of 12 ETC tubes is arranged according to the described configuration, the plant is able to operate a $1.2 \mathrm{~kW}$ steam turbine with an amount of $10 \mathrm{~kW} / \mathrm{m}^{2}$ collected solar radiations at the top of the tower, with required pumping power of $0.2 \mathrm{~kW}$.
The mathematical model of a new designed central receiver performance based on evacuated solar tube configuration has been developed. A good solution for the traditional external and cavity receiver heat losses is proved, the ratio of vapor to liquid in the drum play an essential role in determining the amount of steam generated, dimensions of the receiver and so the size of the plant, elevated temperature expected to achieve and less amount of heat losses. More analysis is required to determine the hydraulic friction losses of the fluid inside the tubes. The design is promised after manufacturing and experimental validation

\section{Acknowledgment}

The authors acknowledge the support from University Teknologi PETRONAS for the research activities, work, and the supply of research facilities.

\section{Nomenclature}

-

$m_{d}$ Steam flows out of the drum $(\mathrm{kg} / \mathrm{s})$

$m_{d c}$ Flow into the downcommer

$m_{f w} \quad$ Feed water flow

$m_{d f}$ Drainage flow

•

$m_{\text {eva }}$ Evaporation steam flow

-

$\boldsymbol{m}_{\text {cond }}$ Condensed steam flow

-

$m_{\text {frin }}$ Flow to the riser

-

$m_{\text {frout }}$ Flow from the riser

-

$m_{\text {supin }}$ Flow to the superheat

$\Delta p_{g r} \quad$ Saturated pressure difference

$\Delta t_{g r} \quad$ Pipe wall over heat rate

$\dot{\boldsymbol{m}}_{\text {supout }}$ Flow from the superheater

$V_{s-\text { drum }}$ Volume of steam in the drum $\mathrm{m}^{3}$

$V_{L-\text { drum }}$ Volume of water in the drum

$\rho^{s w} \quad$ Density of saturated water

$\rho^{s s} \quad$ Density of saturated steam

$H^{s w} \quad$ Enthalpy of saturated water

$H^{\text {ss }} \quad$ Enthalpy of saturated steam 
$H_{\text {supout }}$ Enthalpy of superheated steam

$Q_{g-m} \quad$ Heat loss from steam to drum

$Q_{m-d} \quad$ Heat loss from the drum

$H_{\text {eva } 1}$ Inlet Enthalpy to the evaporation panel

$H_{\text {eva } 2}$ Outlet Enthalpy from the evaporation panel

$Q_{a} \quad$ Heat transfer from pipe wall to fluid

$Q_{f} \quad$ Radiation heat transferred from the field

$T_{j}$ Temperature in evaporation panel tube

$T_{a} \quad$ Fluid temperature in evaporation panel

$M_{a}$ Mass of the fluid in the evaporation panel

$M$

$h$

Mass of the evaporation panel

$h$ Enthalpy of the fluid in the evaporation panel

Re Reynolds number

Pr Prandtl number

$V \quad$ Volume of the evaporation panel

$x \quad$ Mass rate of vapor

$\alpha_{c h} \quad$ Heat transfer coefficient in single- phase

$\alpha_{l} \quad$ Coefficient of heat transfer

$\alpha_{h f} \quad$ Coefficient of heat transfer of boiling

$\alpha_{d l} \quad$ Convective heat transfer

$S \quad$ Heat transfer area

$\lambda \quad$ Heat conduction coefficient of the steam

$\sigma \quad$ Interfacial force coefficient

$d \quad$ Diameter of the tube

$\boldsymbol{U} \quad$ Viscosity of saturated water

$C_{p} \quad$ Specific heat

$k$ Conduction heat transfer coefficient

\section{References}

1. O. Behar, A. Khellaf, and K. Mohammedi, "A review of studies on central receiver solar thermal power plants," Renewable and Sustainable Energy Reviews, vol. 23, pp. 12-39, 2013.

2. H. L. Zhang, J. Baeyens, J. Degrève, and G. Cacères, "Concentrated solar power plants: Review and design methodology," Renewable and Sustainable Energy Reviews, vol. 22, pp. 466-481, 6// 2013.
3. M. Romero, R. Buck, and J. E. Pacheco, "An update on solar central receiver systems, projects, and technologies," Journal of Solar Energy Engineering, vol. 124, pp. 98-108, 2002.

4. J. Muñoz, A. Abánades, and J. M. Martínez-Val, "A conceptual design of solar boiler," Solar Energy, vol. 83, pp. 1713-1722, 2009.

5. Z. Cheng, Y. He, and F. Cui, "A new modelling method and unified code with MCRT for concentrating solar collectors and its applications," Applied Energy, vol. 101, pp. 686-698, 2013.

6. E. Leonardi and B. D'Aguanno, "CRS4-2: a numerical code for the calculation of the solar power collected in a central receiver system," Energy, vol. 36, pp. 4828-4837, 2011.

7. S. H. Teichel, L. Feierabend, S. A. Klein, and D. T. Reindl, "An alternative method for calculation of semi-gray radiation heat transfer in solar central cavity receivers," Solar Energy, vol. 86, pp. 1899. 1909, 2012.

8. I. Hischier, P. Poživil, and A. Steinfeld, "A Modular Ceramic Cavity-Receiver for High-Temperature High-Concentration Solar Applications," Journal of solar energy engineering, vol. 134, p. 011004, 2012.

9. A. Kribus, P. Doron, R. Rubin, J. Karni, R. Reuven, S. Duchan, et al., "A multistage solar receiver:: The route to high temperature," Solar Energy, vol. 67, pp. 3-11, 1999.

10. C. Xu, Z. Wang, X. Li, and F. Sun, "Energy and exergy analysis of solar power tower plants," Applied Thermal Engineering, vol. 31, pp. 3904-3913, 2011.

11. Q. Yu, Z. Wang, E. Xu, X. Li, and M. Guo, "Modeling and dynamic simulation of the collector and receiver system of $1 \mathrm{MWe}$ DAHAN solar thermal power tower plant," Renewable Energy, vol. 43, pp. 18-29, 2012.

12. E. Xu, Q. Yu, Z. Wang, and C. Yang, "Modeling and simulation of $1 \mathrm{MW}$ DAHAN solar thermal power tower plant," Renewable Energy, vol. 36, pp. 848-857, 2011.

13. Z. Yao, Z. Wang, Z. Lu, and X. Wei, "Modeling and simulation of the pioneer $1 \mathrm{MW}$ solar thermal central receiver system in China," Renewable Energy, vol. 34, pp. 2437-2446, 2009. 